10 Sastry-Gollapudi VS, Kind LS. Enhanced reaginic antibody formation to ovalbumin in mice given repeated injections of con A. Int Arch Allergy Appl I mmunol 1977;53:569-73.

11 Freed DLJ. Lectins, allergens and mucus. In: Bøg-Hansen TC, ed. Lectins-biology biochemistry clinical biochemistry. Vol 2. Berlin: Walter de Gruyter, 1982:33-43.

12 Gibbons RJ, Danders I. Lectin-like constituents in foods which react with components of serum, saliva and Strep mutans. Appl Environ Microbiol 1981;41:880-8.

13 Nachbar MS, Oppenheim JD. Lectins in the US diet: a survey of lectins in commonly consumed foods and a review of the literature. Am f Clin Nutr 1980;33:2338-45.

14 Concon JM, Newberg DS, Eades SN. Lectins in wheat gluten proteins. 7 Agric Food Chem 1983;31:939-41.

15 Grant G, More LJ, McKenzie NH, Pusztai A. The effect of heating on the haemagglutinating activity and nutritional properties of bean (Phaseolus vulgaris) seeds. I Sci Food Agric 1982;33: 1324-6.

16 Public Health Laboratory Service. Unusual outbreak of food poisoning. Br Med $\mathcal{F}$ 1976;ii: 1268.

17 Lis H, Sharon N. Lectins in higher plants. In: Stumpf PK, Conn EE, Marcus A, eds. The biochemistry of plants: a comprehensive treatise. Vol VI. New York: Academic Press, 1981:372-447. Nachbar MS, Oppenheim JD, Thomas JO. Lectins in the US diet. Isolation and characterisation Nachbar MS, Oppenheim JD, Thomas JO. Lectins in the US diet. Isolation and characteri
of a lectir from the tomato (Lycopersicon esculentum). $\mathcal{F}$ Biol Chem 1980;255:2056-61.

of a lectir from the tomato (Lycopersicon esculentum). F Biol Chem 1980;255;
19 Freed DLJ, Buckley CH. Mucotractive effect of lectin. Lancet 1978;i:585-6.

20 Pusztai A, King TP, Clarke EMW. Recent advances in the study of the kidney bean (Phaseolus vulgaris) lectins in rats. Toxicon 1982;20:195-7.

21 Brady PG, Vannier AM, Banwell JG. Identification of the dietary lectin wheat germ agglutinin in human intestinal contents. Gastroenterology 1978;75:236-9.

22 Bräuer $R$, Henzgen $S$, Thoss $K$, Waldmann $G$. Biphasic changes of the immunological reactivity in the course of experimental lectin-induced arthritis of rabbits. Exp Pathol 1983;24:117-31.

23 Willoughby WF, Willoughby JB, Cantrell BB, Wheelis $R$. In vivo responses to inhaled protein II: induction of interstitial pneumonitis and enhancement of immune complex mediated alveolitis by inhaled concanavalin A. Lab Invest 1979;40:399-414.

24 Boedecker EC, Boldt DH. Effect of plant lectins on the binding of human intrinsic factor-vitamin $B_{12}$ complex (IF-B 12 ) to isolated guineapig brush border membranes. Gastroenterology 1975;68: B-9/866.

25 Pusztai A, Clarke EMW, Grant G, King TP. The toxicity of Phaseolus vulgaris lectins: nitrogen balance and immunochemical studies. I Sci Food Agric 1981;32:1037-46.

26 Weiser MM, Douglas AP. An alternative mechanism for gluten toxicity in coeliac disease. Lance 1976;i:567-9.

27 Rubin W, Fauci AS, Sleisenger MH, et al. Immunofluorescent studies in adult celiac disease. $f$ Clin Invest 1965;44:475-85.

28 Köttgen E, Kluge F, Volk B, Gerok W. The lectin properties ot gluten as the basis of the pathomechanism vi gluten sensitive enteropathy. Klin Wochenschr 1983;61:111-2.

29 Donovan K, Torres-Pinedo R. Effect of D-galactose on the fluid loss in soybean protein intoler ance [Abstract]. Pediatr Res 1978;12(pt 2):433.

30 Cuatrecasas P, Tell GPE. Insulin-like activity of concanavalin A and wheat germ agglutinindirect interactions with insulin receptors. Proc Natl Acad Sci USA 1973;70:485-9.

31 Livingston JN, Purvis BJ. Effects of wheat germ agglutinin on insulin binding and insulin sensitivity of fat cells. Am $\mathcal{F}$ Physiol 1980;238:E267-75.

32 Schechter Y. Bound lectins that mimic insulin produce persistent insulin-like activities. Endocrinology 1983;113:1921-6.

\section{A Bill that should be stopped}

Last week the House of Commons gave a second reading to Mr Enoch Powell's Unborn Children (Protection) Bill. If this were to become law it would have sweeping effects. In particular, it would go against the recommendations of the Warnock report and prevent a human embryo from being created, kept, or used for any purpose other than enabling a child to be borne by a particular woman. The result would be to stop much of the research into infertility and serious genetic disorders, as well as to threaten the therapeutic in vitro fertilisation programme in Britain. The decision will also distress the thousands of couples who are hoping that future research findings might find new treatments for infertility and for the control of genetic disorders. Far too little time has elapsed since the publication of the Warnock report for calm and informed widespread debate to have taken place; the government should not be rushed into $\underline{\underline{T}}$ allowing premature legislation because of the clamourings of $\frac{\vec{\Phi}}{2}$ some unrepresentative pressure groups.

A majority of the Warnock committee recommended that $\stackrel{c}{\triangle}$ research might be allowed on any embryo up to the 14th day $\cong$ (when the primitive streak is formed), the limit recom- 7 mended by the BMA. ${ }^{1}$ Discussing the arguments about the $\mathbb{\Phi}$ use of human embryos, it stated that though the human embryo is entitled to some added measure of respect beyond that accorded to other animal subjects, such respect cannot be absolute and it must be weighed against the benefits of $\overrightarrow{0}$ research-a view supported by the eminent theologian $\frac{}{0}$ Professor G R Dunstan. ${ }^{2}$ The public interest would be $\frac{\bar{\rho}}{T}$ safeguarded and widespread anxiety allayed by stringent $\stackrel{\varnothing}{\varrho}$ monitoring and controls-including a statutory licensing body (with a lay chairman and substantial lay representa- $\vec{\circ}$ tion), informed consent by the couple for the use of "spare" ? embryos in research, and the prohibition of transferring to a $\vec{\omega}$ woman any embryo that had been used for research. Most of $\frac{\partial}{\partial}$ these recommendations will be introduced by the Medical 3 Research Council in a code of practice designed as an interim measure, which emphasises the important role of additional approval by local ethics committees for individual projects. ${ }^{3}+$ In some diseases research on animal models is impossible and $\infty$ to stop all research on embryos would be to deprive future $\mathscr{\infty}_{\infty}$ generations of the likely benefits, in the understanding and $\frac{0}{2}$ treatment of human infertility, the detection and prevention of congenital and hereditary disorders, the reduction of $\omega$ spontaneous abortion, and improved contraception. It is also $\frac{\mathbb{O}}{O}$ likely that the therapeutic in vitro fertilisation programme would largely stop, given the inevitable overlap between pure and applied research-at least in Britain, for undoubtedly $\vec{\varphi}$ such research would move to countries where it was per- o mitted and encouraged.

Public anxiety on these issues is understandable, and it is up to doctors and philosophers to allay their fears and show the advantages of the techniques. In many ways the current alarmist statements are analogous to those made years ago $\stackrel{\square}{\unrhd}$ about AID (artificial insemination by donor), "human $\overrightarrow{\vec{O}}$ guinea pigs" (experiments in man), and recombinant DNA 3 technology. In each case full debate and explanation without premature and ill considered action allowed the public to understand the issues at stake and, with various provisos, to sanction their practice. This is what should happen in the present case: the government should come off the fence and $\frac{5}{3}$ oppose the Powell Bill on the grounds that its own considered legislation is on the way. It should stick to its plan of $\frac{\rho}{\beta}$ introducing legislation in the latter part of this year after a prolonged, informed, and calm debate has taken place.

1 Committee of Enquiry into Human Fertilisation and Embryology. Report. London: HMSO, 1984 Chairman $M$ Warnock.

2 Anonymous. A welcome report [Editorial]. Br Med f 1984;289:207-8.

3 Anonymous. MRC proposes voluntary body to supervise embryo research. Br Med f 1985;290:400. 